\title{
What does nationality mean today? Construction of national identity of the students who are
} attending Lithuanian schools

\author{
Agnè Juškevičienè \\ Lecturer, Department of Education, \\ Lithuanian University of Educational Sciences \\ Email. agne.juskeviciene@leu.lt
}

DOI:10.5901/mjss.2014.v5n22p20

\begin{abstract}
.
This paper strives to reveal what does nationality as the basic element constructing the national identity means to Lithuanian students attending Lithuanian schools in Lithuania, Poland and Belarus. Empirical qualitative research was conducted from the end of 2013 to the beginning of 2014 with ninth and tenth graders attending Lithuanian schools in Lithuania, Poland and Belarus. The research sample: Lithuania (12 ninth graders; 13 tenth graders); Poland (15 ninth graders; 14 tenth graders); Belarus (4 ninth graders; 5 tenth graders). Study instrument: an essay. Analyzing the study data, categories were distinguished in terms of the structural components of the identity (Herskovits, 1948; Huntington, 1996): 1) national heritage; 2) ethnocentrism; 3) cultural homogeneity; 4) belief structure. The research data reveals that Lithuanian students attending Lithuanian schools in Poland perceive their nationality as encompassing all four components of the national identity. The most explicit reference, as in the case of Lithuanian students attending schools in Lithuania, is to the category of the cultural homogeneity, which involves the most explicit expression of the involvement to the process of fostering the culture. However, in the Lithuanian group, nationality even triggers negative feelings and indifference. The results of qualitative research results in Lithuanian schools in Belarus show that students of these schools identify the state of being a Lithuanian with cultural homogeneity, when they can foster their mother tongue, traditions, customs. etc.; also the students see actual possibilities to associate their future with their homeland, which in this case is Lithuania.
\end{abstract}

Keywords Nationality, National identity, school students in Lithuania, Poland and Belarus.

\section{Introduction}

Identification with nation is one of the most important phenomena in the society; it is realized as the fact when a person considers himself as a part of his nation, accepts and believes in its standard rules, the way of life and knows cultural, material and spiritual heritage. However, personal identification with the national society in the global world becomes increasingly weaker and less significant because people who decide to disassociate from their nation seek to identify themselves with Europe or even with the entire world. Increasing migration, technologies and the progress of communities are reducing the world by bringing people to closer interaction with each other which would not have been possible a few decades ago (J. J. Platt, T. A. Laszloffy, 2013).

Due to being among hybrid, European, cosmopolitan and other identities, a person feels lost. However, negating the national identity, at the same time, we also negate the human origin, i.e. generation from nation. The scientists argue that the national identity itself is the foundation for formation of hybrid, global identity and identification with a nation is considered as a part of full-fledged life of a person. Nationality is a substantial construct of national identity. Language, culture, history and etc. play the same role. Could the state be retained in case of negation of nationality? Can a person live without a nation? We can often hear that globalization destroys nations and etc. By the way, globalization binds the world; however, maybe globalization itself is that specific opportunity of construction of our nations, of development of our culture, of disclosure of its uniqueness and etc. It is worth thinking that maybe the problem is hidden outside the human consciousness and conception of global perception when the nation, culture and etc. are denied. It is worth realizing that the world needs genuine nation that have genuine cultures instead of plagiarism and uniform phenomena. Therefore, the following problem is raised: what does the nationality as the basic element constructing the national identity means to Lithuanian students attending Lithuanian schools in Lithuania, Poland and Belarus. The purpose is to reveal what does the nationality as the basic element constructing the national identity mean to students of Lithuanian schools. The article provides: 
theoretical research - analysis of the chosen aspects of philosophical, psychological, educational and other literature; empirical research - qualitative analysis - essay. This paper introduces content analysis of the essay.

\section{Discourse of nationality}

Even in the 21 st century, the notion of nationality does not have a unified and universally acknowledged definition. For example, the terms nationality and citizenship are usually considered to be synonymous. "We are aware that citizenship and nationality are often used synonymously and that some domestic laws use only the former concept" (R. Bauböck, E. Ersbøll, K. Groenendijk, H. Waldrauch, 2006, p. 2). Thus, the notion of nationality acquires political content, even though the difference in English between those two terms is emphasized. For example, in the United Kingdom, the term nationality is used to mark the official relation between the state and the individual (Gerard-René de Groot, 2004). On the other hand, the authors admit that the term nationality might be ambiguous, as it is connected to the national identity and the membership of national minorities.

However, there are certain authors who attempt to change the dominating traditional system, in which nationality is related to personal faithfulness and dedication to one's nation; these authors tend to focus on political manifestations of the state. Kay Hailbronner perceives nationality as an expression of the membership in a political community, as a legal status and obligation to the political subject which is necessary for existent of a sovereign state.

Analogous approach is introduced by R. Bauböck, E. Ersbøll, K. Groenendijk and H. Waldrauch (2006) who accept the same notion of nationality promoted by the international law, when the nationality is perceived as legal relations between the persons and the nation.

There is a different position as well, as in the case of Tom George (2010) who distinguishes the differences between the citizenship and nationality and marks that nationality is a wider notion than citizenship. It means that nationality is characteristic to all political members of a certain state or for those who are dedicated to the state; however, not all citizens might have citizenship. Also one can have and develop its nationality even if one loses his/her citizenship. However, having lost the citizenship in one's country, the person can lose the right to live in it as well. Nationality is independent or related to the place of residence. The aforementioned aspects introduced by the author show that nationality is internal personal connection with the nation and community. Citizenship is related to the place of residence. This is based on the author's claim that being in the possession of nationality will not unable a person to acquire political rights; citizenship, on the other hand, will grant a person all political rights.

In this paper, nationality and citizenship are treated as different terms. Understandably, nationality cannot be categorically separated from citizenship as well as the nation cannot be separated from the state. However, the essence of the nationality is its personal connection to the nation and belonging to the national community, which occurs not from political laws of the state, but the national culture, customs, etc. The nation is considered to be the basis of nationality. Authors frequently mention culture, history, language, traditions, race as well as territory, politics and economy. All these aspects form the nation (H. R. Isaacs, 2001).

The nation is characterized by concentration of persons, mutual understanding and united actions which can unite people who can improve the quality of the nation, various parts of the state (religion, science, art, etc.) Nationality or individuality of the nation depends on these conditions. However, Stasys Šalkauskis (1991) marks that nationality is not related to various signs of nations, which are necessary for their expression. For example, the language which reflects nationality the best "is not necessarily a quality necessary for the nation. It is true, however, that the lack of national language makes the contents of the nationality poorer and less defined; nevertheless, it would be unjustifiable to insist on the lack of nationality altogether" (Šalkauskis, 1991, p. 66). The philosopher claims that neither manifestation of life of a concentrated (group of people) society is a necessary quality for the nationality. It means that even considering specific manifestations of the nation, it is impossible to draw full definition, which would apply to Jews, Swiss and other nations (Šalkauskis, 1991). Šalkauskis, who analyzed the essence of nationality, claims that the nation are maintained by the nationality as the personalities are maintained by a person; however, both arise from the individuality of the entity. However, the nation is a collective or concentrated individual. The philosopher found highly close connection between the personality and the nationality. He marked that nationality is like a circle surrounding the individual, "supplementing one's personal existence and providing him/her with necessary conditions to full-fledged life" (Šalkauskis, 1991, p. 65). These are uninterruptible connections which relate the nation with the individual. 
According to Šalkauskis (1991), the nation and its constituting factors serve for the development of personality. The final aim of each concentrated group or organization is the full thriving of a person. It helps to create a full-fledged individual. However, some organizations are based on a natural action and the other ones are created artificially. However, the nations organize themselves on the natural basis and "constitutes direct conditions for the development of the full human being.

Antanas Maceina states that the national individuality is determined by the man and his/her nature. However, the nature must be assisted by the culture. "An individual has in itself the essence of national individuality; s/he is its carrier and support" (1991, p. 46). Development of culture is followed by the development of the prominence of the nation as an entity and as an individual. According to Maceina (1991), the process of the nation becoming more prominent is the improvement of national individuality. Historical destiny is the factor that makes the nation prominent.

Therefore, the nationality, i.e. dentification of oneself with a certain community or a nation is a significant element in the construction of the national identity. This work is based on the main components of national identity introduced by Herskovits (1948) and Huntington (1996). According to this structure, the national identity consists of the belief structure, which describes religious beliefs, religious activity related to national participation and unity; national heritage, which reflects feelings and unique history of culture, historical figures, historic events, etc.; ethnocentrism as greater appreciation and worshipping of one's own culture; dedication to the nation; cultural homogeneity is the culture unifying the members of the nation.

In this case, subcultures within the national boundaries have the opposite connection to the power of the national identity (Bruce D. Keillor, G. Tomas M. Hult, 1998). Involvement to activities which identify people as members of the nation.

\section{Research methodology}

Sample and organization of research. Empirical qualitative research conducted from the end of 2013 to the beginning of 2014 with ninth and tenth graders in Lithuanian schools in Lithuania, Poland and Belarus. For the content analysis in this work, ninth graders and tenth graders of Lithuanian schools in Lithuania, Belarus and Poland were selected. The research sample: Lithuania (12 ninth graders; 13 tenth graders); Poland (15 ninth graders; 14 tenth graders); Belarus (4 ninth graders; 5 tenth graders). The instrument was an essay. The students had the topic provided which was "The formation of my national identity" together with key propositions, considering which, the students had to write their paper. One of the key terms was "What does being a Lithuanian (Pole, Belarusian, etc.) mean to me?" The aim of this research was to reveal the attitude, relation to the nationality, the importance of nationality to the respondent (the person himself/herself must realize the truth "self", which is considered to be the essence of identity).

Analyzing the research data on the basis of the structural components of national identity (Herskovits, 1948; Huntington, 1996), the following categories were determined: 1) national heritage; 2) ethnocentrism; 3) cultural homogeneity; 4) belief structure. Categorization depends on the answers of each group of respondents.

\section{Research results}

Relation of Lithuanian ninth and tenth graders in Lithuanian schools to their nationality

Table 1

\begin{tabular}{|l|l|l|}
\hline Category & Sub-category & Confirming statement \\
\hline $\begin{array}{l}\text { National } \\
\text { heritage }\end{array}$ & $\begin{array}{l}\text { Pride in the Achievements } \\
\text { and culture of the Homeland }\end{array}$ & $\begin{array}{l}\text { "This status makes me proud of the best Lithuanian basketball, a } \\
\text { wonderful Olympic champion, delicious traditional food and our } \\
\text { history of recovering independence" ( } \mathrm{n}=5) .\end{array}$ \\
\hline $\begin{array}{l}\text { Ethnocent } \\
\text { rism }\end{array}$ & $\begin{array}{l}\text { Patriotic dedication to the } \\
\text { nation }\end{array}$ & $\begin{array}{l}\text { "In my opinion, being a Lithuanian means to be dedicated to your } \\
\text { homeland Lithuania. It means doing everything for it" (2). }\end{array}$ \\
\hline & Pride in one's nationality & $\begin{array}{l}\text { "Being a Lithuanian for me means having Lithuanian identity, living } \\
\text { here and being proud of it" }(n=6) .\end{array}$ \\
\hline
\end{tabular}




\begin{tabular}{|l|l|l|}
\hline $\begin{array}{l}\text { Cultural } \\
\text { homogen } \\
\text { eity }\end{array}$ & Honor & "In my opinion, being Lithuanian is a great honor..." (n=4). \\
\cline { 2 - 3 } & Sense of community & $\begin{array}{l}\text { "We are living in the country, where Lithuanians constitute the } \\
\text { largest part of inhabitants; the country itself is Lithuanian after all." }\end{array}$ \\
\cline { 2 - 3 } & Origins in the Homeland & $\begin{array}{l}\text { "Being a Lithuanian means that I was born in Lithuania" (n=2). } \\
\text { "I was born in Lithuania and it means a lot to me; I grew up in here, } \\
\text { here I learned a lot and started understanding things. I could not } \\
\text { imagine myself speaking in a different language or living in a } \\
\text { different country. The word Lithuania brings a lot of memories to } \\
\text { mind." }\end{array}$ \\
\cline { 2 - 4 } $\begin{array}{l}\text { Fostering culture (mother } \\
\text { tongue, traditions, etc.) }\end{array}$ & $\begin{array}{l}\text { "...speaking Lithuanian, creating and following Lithuanian } \\
\text { traditions" (n=6). }\end{array}$ \\
\cline { 2 - 4 } & Life in Homeland & "Being a Lithuanian to me means living in Lithuania..." (n=2). \\
\cline { 2 - 4 } & Attending Lithuanian school & "attending Lithuanian school" \\
\hline & $\begin{array}{l}\text { Negative assessment of } \\
\text { nationality }\end{array}$ & $\begin{array}{l}\text { "Being a Lithuanian is not such a grand thing because the country } \\
\text { is collapsing due to economic problems and the response from } \\
\text { other countries is not good as well. I simply know who I am. But of } \\
\text { course I would like not to be a Lithuanian" (n=3). }\end{array}$ \\
\hline & $\begin{array}{l}\text { "Being a Lithuanian is not as different as being a member of a } \\
\text { different country. Each country has its advantages and } \\
\text { disadvantages; therefore, it cannot be said that by being a citizen } \\
\text { of a certain country I am making you ashamed of it" (n=4). }\end{array}$ \\
\hline
\end{tabular}

Analysis of data retrieved from the research with Lithuanian students attending Lithuanian schools in Lithuania shows that cultural homogeneity is the category that was distinguished the most. This component is further divided into subcategories. It is evident that these six respondents perceive nationality as the process of fostering culture (traditions, customs and mother tongue), five respondents mark the pride in their nationality and four students consider nationality as an honor they received. However, four students state that being Lithuanians does not mean anything to them; this reveals their indifference to the nation.

The other category, national heritage, reveals the state of being proud of the achievements and culture of one's Homeland. This is mentioned by six respondents.

Ethnocentricity is described as patriotic dedication to the nation, which was selected by two students. Summarizing, it can be said that for this group of respondents, nationality is a part of cultural homogeneity and cultural uniqueness; however, nationality evokes negative feelings or indifference for five respondents.

\section{Relation of Lithuanian ninth and tenth graders attending Lithuanian schools in Poland to their nationality}

Table 2

\begin{tabular}{|l|l|l|}
\hline Category & Sub-category & Confirming statement \\
\hline $\begin{array}{l}\text { National } \\
\text { heritage }\end{array}$ & $\begin{array}{l}\text { Pride in the } \\
\text { Achievements and } \\
\text { culture of the } \\
\text { Homeland }\end{array}$ & $\begin{array}{l}\text { "To me, Lithuanian origins and history are very important. I really love } \\
\text { to come here"; "one must be proud of Lithuanian language, since it is } \\
\text { one of the oldest surviving languages". }\end{array}$ \\
\cline { 2 - 4 } & $\begin{array}{l}\text { Respect to the } \\
\text { homeland and its } \\
\text { heritage }\end{array}$ & "It means that I respect my nationality, hymn and traditions. In my \\
opinion, being Lithuanian now means respecting the country and
\end{tabular}




\begin{tabular}{|c|c|c|}
\hline & & $\begin{array}{l}\text { loving and not forgetting it. Being a Lithuanian means respecting its } \\
\text { mother tongue". (3) }\end{array}$ \\
\hline $\begin{array}{l}\text { Belief } \\
\text { system }\end{array}$ & Religious activity & "I go to church every Sunday. Here, Lithuanian mass is held" \\
\hline $\begin{array}{l}\text { Ethnocent } \\
\text { rism }\end{array}$ & $\begin{array}{l}\text { Patriotic dedication } \\
\text { to the country }\end{array}$ & $\begin{array}{l}\text { "Being a Lithuanian means supporting Lithuanian sportsmen" (2); } \\
\text { "Being a Lithuanian to me means being a patriot" (6). }\end{array}$ \\
\hline \multirow{9}{*}{$\begin{array}{l}\text { Cultural } \\
\text { homogene } \\
\text { ity }\end{array}$} & $\begin{array}{l}\text { Pride in one's } \\
\text { nationality }\end{array}$ & $\begin{array}{l}\text { "Being a Lithuanian in Poland means a lot to me. I am proud of who I } \\
\text { am and I do not want to be a different person" (4). }\end{array}$ \\
\hline & Honor & $\begin{array}{l}\text { Being a Lithuanian is a great honor and pride. Being a Lithuanian is } \\
\text { an honor. }\end{array}$ \\
\hline & Sense of community & $\begin{array}{l}\text { "Being a Lithuanian or a Pole means a lot because I can communicate } \\
\text { with others" }\end{array}$ \\
\hline & $\begin{array}{l}\text { Origin in the } \\
\text { Homeland }\end{array}$ & "Being a Lithuanian means a lot because it is my home nation." \\
\hline & $\begin{array}{l}\text { Fostering culture } \\
\text { (mother tongue, } \\
\text { traditions, etc.) }\end{array}$ & $\begin{array}{l}\text { "Being a Lithuanian means celebrating its occasions and following its } \\
\text { traditions. Being Lithuanian is very important, especially cherishing } \\
\text { its language so it would not disappear. It is as if honoring the works } \\
\text { of our ancestors, who fought for Lithuanian language" (19). }\end{array}$ \\
\hline & $\begin{array}{lr}\text { Positive } & \text { feelings } \\
\text { towards } & \text { the } \\
\text { nationality } & \end{array}$ & $\begin{array}{l}\text { "Being a Lithuanian means a lot to me. I am happy because this is } \\
\text { my nationality. In my heart, I always feel ove for Lithuania, which I } \\
\text { received from my parents" (7). }\end{array}$ \\
\hline & $\begin{array}{lr}\text { The } & \text { historic } \\
\text { importance } & \text { of } \\
\text { continuity } & \text { of } \\
\text { nationality } & \end{array}$ & $\begin{array}{l}\text { "To me, being a Lithuanian means everything. I received my } \\
\text { character traits determining my national identity from my } \\
\text { grandparents". }\end{array}$ \\
\hline & $\begin{array}{l}\text { Negative influence of } \\
\text { other countries }\end{array}$ & $\begin{array}{l}\text { "To me, being a Lithuanian is very difficult at the moment because I } \\
\text { live in Poland and it changes everything. Every day now I have to } \\
\text { speak not only in Lithuanian, but also Polish and English ..." }\end{array}$ \\
\hline & $\begin{array}{l}\text { Indifference to the } \\
\text { nation }\end{array}$ & $\begin{array}{l}\text { "At the moment being a Lithuanian to me means living next to it, } \\
\text { behind its border. I would not want to move to Lithuania because here } \\
\text { I would have to leave my friends and family." }\end{array}$ \\
\hline
\end{tabular}

The attitude of Lithuanian students attending Lithuanian school in Poland to the nationality encompasses all four components of national identity. As in the cases of Lithuanian schools in Lithuania, a prominent category is that of cultural homogeneity, in which involvement to the activity fostering cultural activities becomes evident $(n=19)$. Therefore, nationality as a part of cultural uniqueness triggers positive feelings $(n=7)$ and makes people proud of it $(n=4)$.

The other category is cultural heritage which for Lithuanian students living in Poland means the respect for the Homeland, its heritage $(n=3)$; pride in the achievements and culture of Homeland $(n=1)$.

The analysis of data distinguished the category of ethnocentrism, which reveals the subcategory of patriotic dedication to the nation $(n=8)$.

It is noteworthy that in this group of respondents, the component of belief structure has been distinguished, where one student related being Lithuanian to religious activity $(n=1)$.

Relation of Lithuanian ninth and tenth graders attending Lithuanian schools in Belarus to their nationality 
Table 3

\begin{tabular}{|l|l|l|}
\hline \multicolumn{1}{|c|}{ Category } & Sub-category & Confirming statement \\
\hline Cultural homogeneity & $\begin{array}{l}\text { Fostering culture } \\
\text { (mother tongue, } \\
\text { traditions, etc.) }\end{array}$ & \\
\cline { 2 - 3 } & $\begin{array}{l}\text { Possibility to link one's } \\
\text { future with the } \\
\text { homeland }\end{array}$ & "I can study in Lithuania"(3). \\
\cline { 2 - 3 } & $\begin{array}{l}\text { Participation in the life } \\
\text { of the nation }\end{array}$ & "To have interest in Lithuanian life". \\
\hline
\end{tabular}

Since the sample of the group from Belarus was the smallest, it is believable that this factor had influence on narrower interpretation of the data. It has been noticed that Lithuanian students of Lithuanian schools in Belarus relate being Lithuanian to cultural homogeneity, when they can foster their mother tongue, traditions, customs, etc. $(n=9)$. As opposed to the answers in other groups, three students from Belarus see actual possibilities to see their future in Lithuania. The involvement to the life of Lithuania is foreseen only by one respondent.

\section{Conclusions}

1. The analysis of theoretical material presupposes that the notion of nationality does not have a unified notion to this day. In the works of certain scholars, nationality and citizenship are treated as synonyms, thus, attributing political and legal meaning to the nationality. Other scholars emphasize that the essence of nationality is one's personal connection with the nation, belonging to the national community, occurring not from political laws of the state but the culture and customs of the nation, etc. Nationality is one of the main constituents of the national identity.

2. Research data revealed that the attitude of Lithuanian students attending Lithuanian schools in Poland to their nationality encompasses all four components of national identity, namely cultural homogeneity, ethnocentrism, national heritage and belief structure. The most prominent is the category of cultural homogeneity, which reveals involvement to the process of fostering culture the most. It is noteworthy that in the group of these respondents belief structure was revealed, when one student related being Lithuanian to religious activity.

3. The data analysis of research conducted in Lithuanian schools in Lithuania shows that the most prominent component is cultural homogeneity, when the fostering of cultural components (traditions, customs and mother tongue) is emphasized and pride in one's nationality is taken. However, nationality in the group of Lithuanian residents causes negative feelings or indifference as well.

4. The sample of students attending Lithuanian schools in Belarus was the smallest. The results of quantitative research show that students related the state of being Lithuanians to cultural homogeneity, when they can cherish their mother tongue, traditions, etc. also students see actual possibilities to see their future in their homeland, which in this case is Lithuania.

\section{References}

Bauböck, R., Ersbøll, E., Groenendijk, K., Waldrauch, H. (eds.). (2006). Acquisition and loss of nationality. policies and trends in 15 european states summary and recommendations, Available from: http://cmr.jur.ru.nl/CMR/docs/natacsummary.pdf

George, T.(2010). Nationality, Available from: http://www.scribd.com/doc/30077222/Nationality 
Groot, de Gerard-René (2004). Towards a european nationality law, Electronic Journal of Comparative Law, vol. 8.3, Available from: http://arno.unimaas.n//show.cgi?fid=1191

Hailbronner, K. Nationality in public international law and european law, Available from: http://eudocitizenship.eu/docs/chapter1 Haillbronner.pdf

Huntington, S. (1996). The Clash of Civilizations and the Remaking of World Order, Simon and

Schuster, New York, NY, Available from: http://www.stetson.edu/artsci/political-science/media/clash.pdf

Isaacs, Harold R. (2001). Nationality: "End of the road?", Foreign Affairs, Apr 75, Vol. 53 Issue 3, 422-449.

Keillor, Bruce D., Tomas, M. G. Hult. (1998). A five-country study of national identity Implications for international marketing research and practice, International Marketing Review, 16, 1, 65-82.

Maceina, A. (1991). Raštai.I. Vilnius: Mintis.

Platt, Jason J., Laszloffy Tracey A. (2013). Critical patriotism: incorporating Nationality into MFT education and training, Journal of Marital and Family Therapy, Private Practice Norwich, Connecticut, 39 (4), DOI: 10.1111/j.17520606.2012.00325.x, 441-456.

Šalkauskis, S. (1991). Pedagoginiai raštai, Kaunas: Šviesa. 